\title{
art libraries ournas
}

The visual resources profession:

the past and the way forward

Images for Corbis

The Mass-Observation Archive

Collecting artists' videos

Reviews

Art librarianship 2003: the annual bibliography
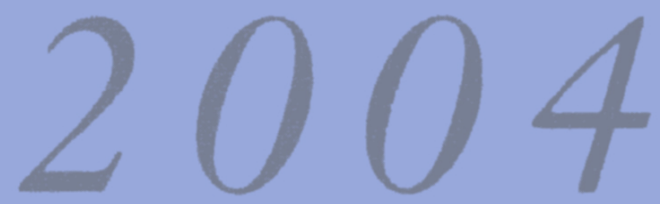

\section{Volume 29}

\section{Number 1}

Revue de Bibliothèques d'Art

Zeitschrift für Kunstbibliotheken

Revista de Bibliotecas de Arte 


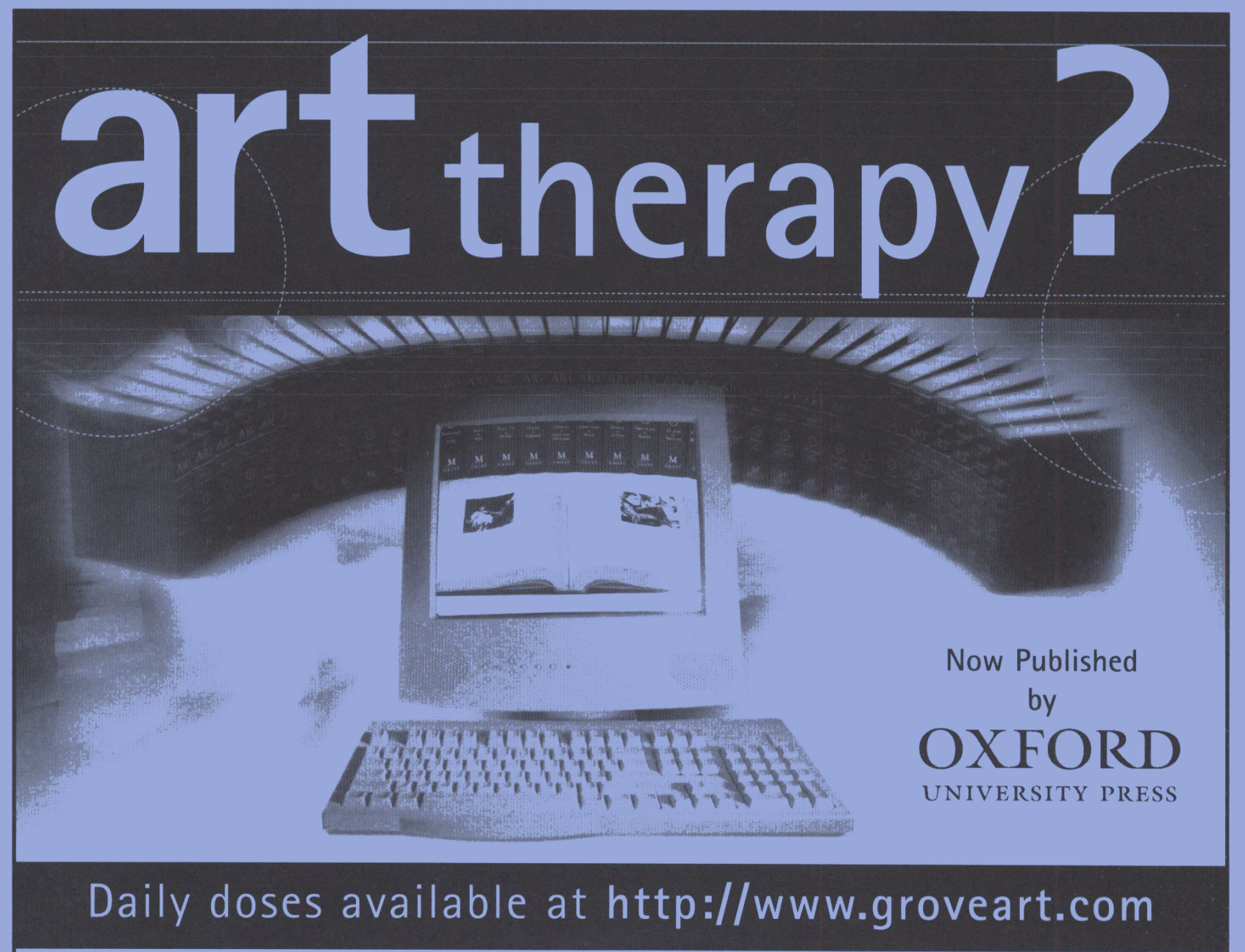

The Grove Dictionary of Art Online

- is founded on the research of over 6,800 internationally-renowned scholars

- contains over 30,000 articles, encompassing the entire history of artistic thought from Palaeolithic cave and rock art to the sculptures of Jake and Dinos Chapman

- offers 86,000 cross-references that ensure accurate information gathering and stimulate new lines of enquiry - includes 720,000 index entries to allow researching a single topic across multiple articles

- contains more than 30,000 external image links and over 100,000 images available from the Bridgeman Art Library, the world's leading source of fine art images

- has regular updates to the text, including newly-commissioned articles to ensure that the resource continues to be the world's premier provider of art and cultural information on the Internet

\section{The Grove Dictionary of Art (34-volume print edition)}

- comes in deep-green, smyth-sewn, cloth bound volumes and has been called the most ambitious project in the history of art publishing

- is the largest collaboration in the history of art publishing with contributions from over 120 countries leading to in-depth cultural and regional diversity

- contains more than 15,000 illustrations

Please contact Oxford University Press fax +44 (0)1865 267308 or e-mail evansri@newgrove.com to discuss: - Other Oxford University Press online services

- Training and update sessions

- Special prices for The Grove Dictionary of Art

- Library-mask linked access

Alternatively you can visit: http://www.e-grove.com or http://www.oxfordonline.com UNIVERSITY PRESS 


\section{- art libraries \\ journal}

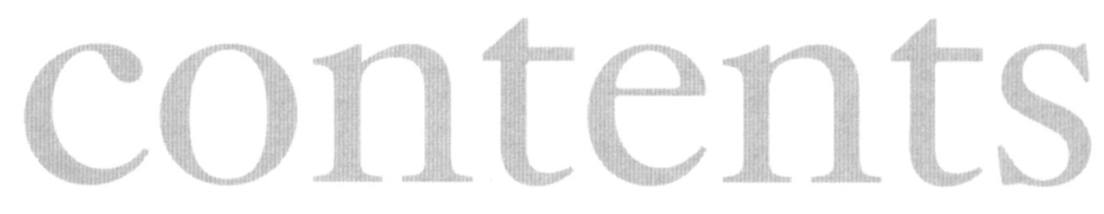

3 Viewpoint: Archival digital? Susan Jane Williams

5 The indivisibility of art librarianship revisited Wolfgang Freitag and Martba Mabard

10 A digital future for slide libraries? Jenny Godfrey

23 An introduction to Corbis and the Corbis Education offering

Adam Young

30 Images of Britain: Mass-Observation 1937-2003 Dorotby Sheridan

35 Diverse practices: video art and libraries Annamarie McKie, Jill Trumper and Nicbolas Turner

42 Review Jim Carmin

45 Art librarianship 2003: the annual bibliography compiled by Gillian Varley 
Editor:

Gillian Varley

10 Prevetts Way

Aldeburgh

Suffolk IP15 5LT

UK

Tel: $+44(0) 1728451948$

Fax: $+44(0) 1728452460$

Email: g.varley@arlis2.demon.co.uk

Reviews Editor:

Barbara Polowy

Art Librarian

Hillyer Art Library

Smith College

Northampton, MA 01063

USA

Tel: +14135852941

Fax: + 14135856975

Email: bpolowy@email.smith.edu

Items for review should be sent to the Reviews Editor's address
The Art libraries journal is published by ARLIS/UK \& Ireland for the international art library community and for all who are interested in the documentation of the visual arts. It highlights the rapid changes in information technology which are affecting the activities of the profession, and documents developments in the converging fields of libraries, museums, archives and visual resources. At the same time it is a journal rooted in the long-term concerns of art librarians, dealing with practical issues relating to traditional art library materials such as exhibition and sales catalogues, visual resources and artists' books.

Most issues of the $A L J$ cover a wide spread of subjects; some focus on specific themes such as digitisation or museum libraries, or more contentious topics such as copyright or charging for services. Certain issues are devoted to aspects of art documentation in a particular country or region.

The majority of the $A L J$ 's articles are specially commissioned from leading art librarians and other specialists. Conference papers from round the world are also published, including a selection from the IFLA Section of Art Libraries workshop and open session each year.

The Editor of the $A L J$ welcomes contributions, especially to the two annual bibliographies, and also correspondence, and these should be sent to the email address on the left.

While most articles are published in English, the Art libraries journal occasionally publishes in French, German and Spanish, with summaries in English.

The $A L J$ appears quarterly, and goes to libraries and individuals in over 45 countries.

The Art libraries journal is available worldwide with membership of ARLIS/UK \& Ireland and costs $£ 41$ for individuals (within the UK and Ireland only); for institutions it is $£ 61 / \$ 122$ (surface mail) or $£ 72 / \$ 144$ (airmail). Non-members outside the UK and Ireland can subscribe to the Art libraries journal for $£ 52 / \$ 104$ (surface mail) or $£ 61 / \$ 122$ (airmail).

Single copies may be purchased at $£ 13 / \$ 26$ each, surface mail postage included ( $£ 12 / \$ 24$ to ARLIS/UK \& Ireland members).

A limited number of complimentary subscriptions to the Art libraries journal is available, for periods of up to two years, to libraries which because of currency problems or other difficulties are genuinely unable to subscribe in the normal way. Applicants are invited to write to the Editor in the first instance.

Membership, subscription and advertising enquiries should be sent to Sonia French, Administrator ARLIS/UK \& Ireland

18 College Road

Bromsgrove, Worcs. B60 2NE, UK

(Tel/fax: +44 (0)1527 579298; Email: sfrench@arlis.demon.co.uk) 